\title{
A HUNGARIKUMOK SZEREPE A VIDÉKFEJLESZTÉSBEN BÁTYA PÉLDÁJÁN KERESZTÜL
}

THE ROLE OF HUNGARICUMS IN RURAL DEVELOPMENT THROUGH THE EXAMPLE OF BÁTYA VILLAGE

\section{Ritter Krisztián PhD.}

egyetemi docens

Szent István Egyetem, Gazdaság- és Társadalomtudományi Kar, Regionális Gazdaságtani és Vidékfejlesztési Intézet

E-mail: ritter.krisztian@gtk.szie.hu

\section{Összefoglalás}

A hungarikumok mint endogén erőforrások szerepét a terület- és vidékfejlesztésben régóta hangsúlyozza a szakirodalom. Egy falukutató tábor keretén belül kifejezetten egy mezőgazdasági terméknek mint endogén erőforrásnak a szerepét vizsgáltuk egy vidéki település, a Kalocsa melletti Bátya esetében, különös tekintettel a foglalkoztatásra, illetve a helyi termék-előállításra. A falu történetében a füszerpaprika-termesztés kiemelkedő. A primer kutatás eredményei alapján, a mezőgazdaság foglalkoztatási szerepkörének általános visszaesése mellett, a paprikatermesztés ugyan még mindig kimutatható hatással van a település életére, és potenciállal rendelkezik a helyi fejlesztések tekintetében, ugyanakkor az ágazatot érintő problémáknak köszönhetően kérdéses, hogy ezt az endogén tényezőt mennyi ideig tudja megőrizni Bátya.

\begin{abstract}
The role of hungaricums (hungarian national values) as endogenous resources in territorial and rural development has been emphasized by the literature. During a summer research camp, especially the role of an agricultural product as an endogenous resource in rural development was analyzed in a rural settlement - Bátya village (Hungary). Bátya is very famous for as an origin of a hungaricum - the Kalocsa (central city nearby) "paprika" (chilli pepper). Parallel to the general decreasing tendency of agricultural employment, in spite of the still significance presence of agricultural production and its potential in local economic development in the village, the future role of the examined hungaricum product as an endogenous competitive local factor seems quite questionable according to our results.
\end{abstract}

Kulcsszavak: endogén erőforrások, élelmiszer, hungarikumok, versenyképesség, vidékfejlesztés

JEL besorolás: Q19, R19

LCC: S539, HD1501

\section{Bevezetés}

Összhangban az Európában elterjedt területfejlesztési filozófiához, Magyarországon is rendkívül fontos szerepet kapnak a helyi, belső (vagy divatosabban endogén) erőforrások mint az önerőből történő építkezés alapkövei. Kiemelt fontosságot szerzett azoknak a tényezőknek a meghatározása, felkutatása, megszerzése vagy kialakítása, melyek egy-egy terület „önálló” gazdasági-társadalmi fejlődéséhez, fejlesztéséhez mint kiinduló kínálati elem járulnak hozzá. A hungarikumok mint sajátos, egyedi és versenyképes eröforrások területi fejlödésben betöltött/betölthető szerepét (területi jelentőségét), a helyi fejlesztésekkel és endogén 
elméletekkel kapcsolatos szakirodalom, valamint a vonatkozó kutatások is körvonalazzák (ld. pl.: Kassai et al., 2016; Ritter és Virág, 2015).

Nem véletlen, hogy a magyar nemzeti értékekröl és a hungarikumokról szóló 2012. évi XXX. törvény szerinti települési, tájegységi, megyei és országos nemzeti értékek és hungarikumok gyüjtése, rendszerezése, a Magyar Értéktárban és a Hungarikumok Gyüjteményében nyilvántartott egyes nemzeti értékek és hungarikumok kollektív megismertetése, azok hazai, külhoni és nemzetközi rendezvényeken, írott és elektronikus kiadványokban történő megjelentetése és népszerüsítése a hazai vidékfejlesztés egyik kitüntetett célja. A vidéki térségek számára ugyanis - a sokszor egyértelmüen az agráriumhoz köthető - hungarikumok megjelenése, előállítása, a rá fonódó gazdasági-, társadalmi tevékenységek, és azok szélesebb értelemben vett területi hatásai egyértelmü versenyképességi tényezőként jelentkezik, mely a fejlesztési irányvonalak meghatározásakor, és azok végrehajtásakor a vidékfejlesztés aktorai számára jelentős potenciált hordoz.

A világgazdaságban lejátszódó folyamatok, a globalizáció, az európai gazdaság térszerkezetének átrendeződése, az utóbbi évtizedekben a területi politika át/felértékelődéséhez vezetett. Mind a nemzeti kormányok, mind pedig az Európai Unió (EU) jelentősen átalakította a területfejlesztés cél-, eszköz-, és intézményrendszerét. Módosultak az alkalmazott alapelvek, a területi egyenlőtlenségek mérséklését szolgáló célok mellett egyre nagyobb súllyal szerepelnek az európai gazdasági tér, illetve az egyes lokalitások versenyképességének erősítését szolgáló intézkedések.

A területi verseny, mint a területi egységek közötti verseny fogalma már általánosan elfogadott, a témának igen széleskörü irodalma van (ld. többek közt Chesire, 2003; Horváth, 2006; Lengyel, 2003; Lukovics és Kovács, 2008). Lengyel alapján ,a területi verseny olyan folyamat, melynek során adott terület helyi gazdaságfejlödését bizonyos csoportok a helyi politikákon keresztül, más területi egységekkel versengve próbálják befolyásolni, explicit vagy gyakran implicit módon" (Lengyel, 2003, 153.o.). A versenyképesség pedig - a szakirodalomban általánosan használt értelemben - a megváltozott, globális feltételekhez való alkalmazkodás képességét jelenti, és fő célja a viszonylag magas jövedelem és magas foglalkoztatottsági szint megteremtése, az adott terület lakosságának az életszínvonal növelése (EC, 1999).

A globalizáció alapvető következménye a térségek, lokalitások szerepének megváltozása és felértékelődése, ami azt is eredményezi, hogy a versenyképesség feltételeinek a kialakítása mára nem csupán a kormányok felelösségkörébe tartozik, hanem az endogén fejlődéselméletek, a saját erőből történő építkezés előtérbe kerülésével, az egyes települések, térségek feladatává is vált. Lényegében ,az új területi politikák homlokterébe a térségek, régiók adottságai, potenciáljai kerültek, melyek a fejlesztésekhez mint belsö, endogén eröforrások állnak rendelkezésre, és megfelelö körülmények közt aktivizálhatók” (Káposzta 2007: 89. o.).

A világgazdaság globalizálódásának fokozódása, a kiéleződő területi verseny, az egyre komplexebb üzleti környezet megteremtésének fontossága előtérbe helyezik az adott térség szereplőit összefogó és koordináló, alulról építkező, kifejezetten a helyi, endogén erőforrásokra építő helyi gazdaságfejlesztési stratégia kidolgozásának, megvalósításának igényét (ld. erről többek közt Áldorfai és Czabadai, 2014; Áldorfai et al., 2015; Moseley, 2003; Tóth és Káposzta, 2014). Ez kifejezetten vidékfejlesztési szempontból is értelmezhető, hiszen az Unió vidékpolitikájának megfelelően, „a szélesebb vidéki gazdaságra vonatkozó intézkedéseket lehetőleg helyi fejlesztési stratégiákon keresztül kell végrehajtani” (EC 2005: 5. o.).

A vidékfejlesztéssel foglalkozó szakemberek szerint ezek a fejlesztések akkor lehetnek eredményesek, ha - miközben a regionális és globális hálózatokhoz való kapcsolódást teszik lehetővé (Lowe et al., 1995), teret adnak a helyi részvételnek (participation) és a helyi kezdeményezéseknek (Cernea, 1992) - egyértelmüen az adott terület helyi (természeti, 
gazdasági, humán, kulturális) erőforrásaira alapoznak (Kulcsár 2006; Ploeg és Dijk 1995). Eközben az önerős fejlesztés révén hosszú távon elszakadnak a külső támogatás okozta függőségtől, és a fenntartható fejlődést szolgálják (Murdoch, 1995). Kulcsár (2006) alapján a helyi erőforrások (local resources) mellett, a helyi tevékenységek (local activities) és a helyi szereplők (local actors) fontossága, valamint az integrált megközelítés is meghatározó.

A gazdaság alakító tényezőinek, alapvető folyamatainak lényeges eleme a vidék fogalmának megerösödése, átalakulása, új szerepkör betöltése is, hiszen a fejlett országokban a vidék fogalma már jó ideje egy teljesen új társadalmi és gazdasági dimenziót fejez ki. A Közös Agrárpolitika (KAP) célkitüzésein és intézkedésein keresztül tetten érhető, hogy az EU a mezőgazdaságnak és a vidéknek már multifunkcionális szerepkört tulajdonít. A multifunkcionalitás alapgondolata szerint a vidéki népesség jövedelme nem kizárólagosan csak az elsődleges funkcióból, élelmiszer és ipari nyersanyag-termelésből, hanem a kulturális és környezeti feladatok ellátásából is származik (Kopasz 2005). A mezőgazdálkodás európai modelljében, a többfunkciós mezőgazdaság és az annak helyet adó vidék, az élelmiszertermelés mellett ökológiai-környezeti, valamint társadalmi-, gazdasági-, szociális-, kulturális funkcióját is betölti. Ezekbe tartozik többek közt a rekreáció és a turizmus feltételeinek megteremtése; a kis- és középvállalkozások támogatása; a vidéki közösségek ápolása; a tájképi és népi kulturális örökség fenntartása; a hagyományok ápolása, az agrár-környezetvédelem stb. (Madarász, 2004). Emellett természetesen olyan versenyképes mezőgazdaságról is beszélünk, amely úgy alkalmazkodik a világpiachoz és a globalizációhoz, hogy a gazdálkodóknak megfelelő életszínvonalat és stabil jövedelmet is nyújt. Ezekhez a multifunkciókhoz a hungarikumok mint tradicionális vidéki termékek, illetve a köréjük füződő tevékenységek, szokások és események jelentősen hozzájárulnak. Ezek közül kiemelhetők az élelmiszertermékek, a rájuk füződő gasztronómiai események, és szoros összefüggésben a turizmus (ld. pl. Bakos és Topa, 2016; Nagy et al., 2012).

Fenti szakirodalmi elméletekből és eredményekből kiindulva felmerül a kérdés, hogy egy hagyományos mezőgazdálkodási alapokon nyugvó, különleges nemzeti értékként nyilvántartott, feldolgozott élelmiszer-termék, mint különleges endogén erőforrás milyen szerepet játszik egy település életében, és hogy a helyi fejlesztési stratégiában milyen pozíciót foglal el. A következőkben bemutatott primer kutatásunk során ennek körbejárása volt az egyik kitüntetett célunk.

\section{Anyag és módszer}

A Szent István Egyetem (SZIE) Regionális Gazdaságtani és Vidékfejlesztési Intézete évente rendez falukutató táborokat, melyek vidékfejlesztési szempontból egy-egy különleges helyzetben lévő településre irányulnak. 2016 augusztusában ennek a tábornak a Bács-Kiskun megyei Bátya adott helyet, mely a kalocsai füszerpaprika őrlemény termesztési területének tagja. A kutatásban a SZIE és a gödöllői Török Ignácz Gimnázium, valamint a Pázmány Péter Katolikus Egyetem oktatói, hallgatói, doktoranduszai vettek részt.

A mezőgazdaság hosszú évszázadok óta fontos szerepet tölt be a vizsgált település életében. Ugyanakkor az agráriumot jellemző átalakulás és tendenciák nem hagyták érintetlenül a falut sem. A kutatás alapvető célja a település gazdasági- társadalmi-, környezeti állapotának felmérése volt, melyben fontos alcélként szerepelt annak feltárása, hogy a gazdálkodás milyen szerepet tölt be a település életében, milyen lehetőségek kapcsolhatók hozzá a település hosszabb távú fejlesztését illetően. Ezzel párhuzamosan, kapcsolódva az RGVI-ben már évek óta folyó - a hungarikumok területi szerepét vizsgáló - tematikus vizsgálatokhoz, határozott és elkülönített fontosságot kapott a füszerpaprika-őrlemény szerepének meghatározása. 
Fentiek vizsgálata kétirányú volt. Első megközelítésben a rendelkezésre álló statisztikai adatok mentén, lehetőség szerint tendenciózusan gyüjtöttük össze a települést jellemző adatokat. Ezek forrása a KSH adatbázisai, a népszámlálások, valamint az Általános Mezőgazdasági Összeírás (ÁMÖ) adatai voltak. Jelen cikk ezeket az adatokat csak érintőlegesen közli, mivel egy korábbi cikk már részletesebben foglalkozott ezekkel.

A szekunder elemzésen túlmenően a falukutató tábor során kérdőíves, illetve ehhez kapcsolódó, kifejezetten az agrárium szerepét célzó kiegészítő, strukturált mélyinterjúkra alapozó primer kutatás végeztünk. A lakossági kérdőív mezőgazdaságra, háztáji gazdálkodásra vonatkozó tematikus kérdéseivel a lakosság általános ,agrár-kitettségét” próbáltuk feltérképezni, míg az előzetes vizsgálatok, valamint a kérdőíves vizsgálat közben „reflektorfénybe kerülő” jelentősebb mezőgazdasági vállalkozók, őstermelők, gazdálkodók, illetve a település vezetőinek, meghatározó személyeinek véleményét és meglátásait mélyinterjúk során gyüjtöttük össze. A kérdőívezés során a 2000 fös településen a háztartások egyharmadát kérdeztük le irányított mintavétellel, az interjúalanyok kiválasztása célzottan történt. A következőkben kifejezetten a füszerpaprika termelésével és feldolgozásával kapcsolatos eredmények kerülnek közlésre.

\section{Kutatási eredmények}

A „Kalocsai füszerpaprika-őrlemény” a Kalocsai tájkörzetben megtermelt, államilag elismert fajtájú fémzárolt vetőmagból származó füszerpaprika növény megszárított termésének megőrlésével készül. Az őrlemény jellemző ízét, aromáját és színét a tájkörzetben nemesített és termelt füszerpaprika fajtáinak, valamint az alapanyag feldolgozása során alkalmazott technológiai és minőségirányítási rendszereknek köszönheti.

Előállításához a Favorit, Folklór, Kaldóm, Kalocsai merevszárú 622, Kalocsai 50, Kalocsai 801, Kalocsai V-2, Kalorez, Kaldóm, Delikát F1, Remény, Rubinvörös, Szegedi 20, Szegedi 80, Kalóz, Jubileum F1, Szikra F1 elnevezésű fajták használhatók fel.

A termesztési körzetet államilag első ízben 1934-ben határozták meg. Az azóta a mezőgazdasági alapanyag termelésben, a tulajdoni szerkezetben, valamint az örlemény piaci helyzetében lezajlott változások hatására a korábbi körzethatárok módosultak. A Kalocsai tájkörzet területén az alábbi települések közigazgatási határain (1. ábra) belül termesztett nyers füszerpaprika használható fel az oltalom alatt álló eredet-megjelöléssel védett termék alapanyagaként: Baja, Bátya, Bogyiszló, Drágszél, Dunaszentbenedek, Dunatetétlen, Dunavecse, Dusnok, Érsekcsanád, Fajsz, Fadd, Géderlak, Hajós, Homokmégy, Kalocsa, Sükösd, Szakmár, Ordas, Öregcsertő, Uszód (Hungarikumok Gyüjteménye,2017). Az eredetvédett termék hungarikumként van nyilvántartva.

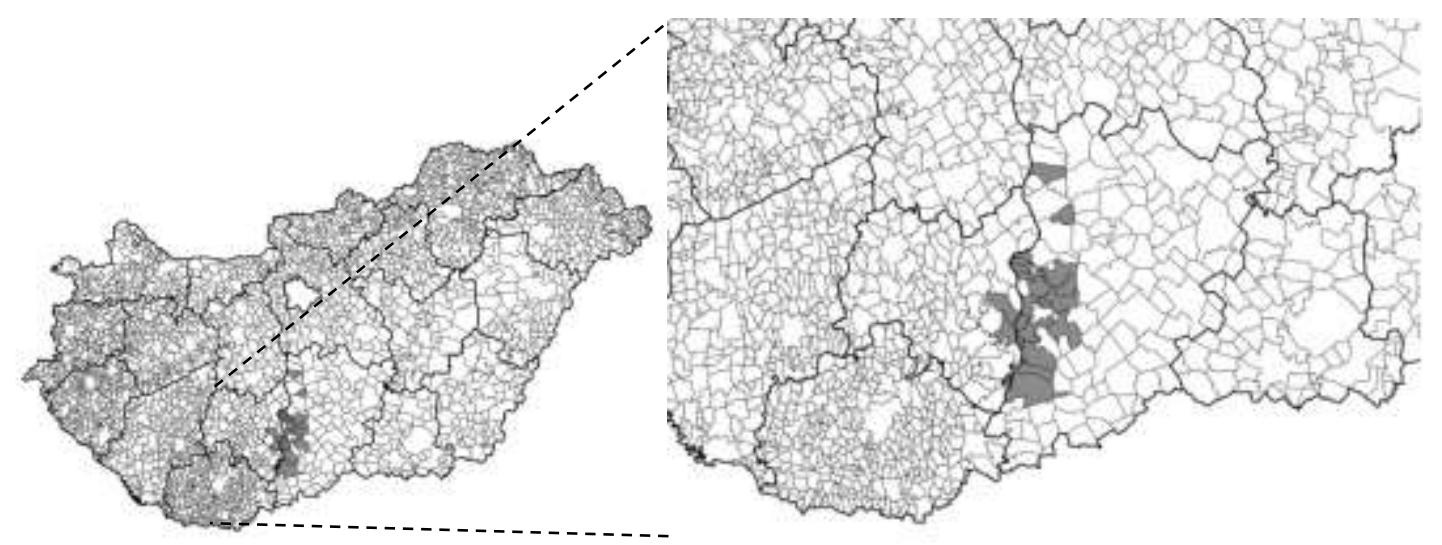

1. Ábra: Az eredetvédett Kalocsai füszerpaprika-őrlemény termesztési körzete Forrás: Saját szerkesztés, 2017 
A hungarikum olyan megkülönböztetésre, kiemelésre méltó magyar nemzeti érték, amely több évszázada vagy nemzedékek során, vagy akár a közelmúltban történt létrejötte révén a történelmi és a mai Magyarországra jellemző mivoltával, egyediségével, különlegességével és minőségével a magyarság szimbólumává vált, továbbá belföldön és külföldön egyaránt tükrözi a magyarsághoz tartozást, továbbá amelyet az e törvény végrehajtására kiadott jogszabályban meghatározottak szerint végzett egyedi értékelés eredményeként a Hungarikum Bizottság (HB) hungarikummá minősít, vagy amely e törvény erejénél fogva hungarikumnak minősül. A Hungarikumok Nemzeti Gyüjteménye a nemzeti értékek köréből a HB által hungarikummá nyilvánított, valamint e törvény erejénél fogva hungarikumnak minősülő nemzeti értékek gyüjteménye.

Nemzeti Érték az a sajátosan magyar szellemi-termelő tevékenységhez, termelési kultúrához, tudáshoz és hagyományokhoz kapcsolódó szellemi, termelő vagy müvészeti tevékenység eredményeként létrejött egyedi, különleges produktum, valamint azon egyedi, különleges természeti érték, amely hazai szempontból meghatározó jelentőségü, így a magyarországi lakosság - de legalább egy meghatározott tájegység lakossága - magyarságra jellemzőnek és közismertnek fogad el, és amely külföldön is magyar sajátosságként ismerhető és ismertethető meg. (2012. évi XXX. törvény a magyar nemzeti értékekről és a hungarikumokról)

A vizsgált település mezőgazdálkodását illetően a XIX. sz. közepéig jellemző termény a gabona (föleg búza), a kukorica, de megemlíthető a len és a kender is. Ugyanakkor a természeti adottságoknak, az elaprózódott birtokszerkezetnek köszönhetően meghonosodott zöldségtermelés és kertészkedés - mely korábban nem volt kizárólagos ágazat - fokozatosan kezdett megerősödni, és nemcsak a zsellérek, hanem a bátyai közbirtokos nemesek is el kezdtek foglalkozni vele (ekkor káposzta, paprika, krumpli, hagyma, bab, fokhagyma termelése a jellemző). A XIX. sz. második felétől növekedésnek indul a kertek mérete, intenzifikálódik a termelés, kapitalizálódik a kereskedelem, nő a befolyó jövedelem. Ekkor már „a bátyai nép hagyományos táji munkamegosztásából eredö paraszti, majd mindinkább kapitalizálódó áruértékesitö tevékenysége társadalomstruktráló következményekkel jár" (Fehér, 1996: 179180. o.). Ebben az időszakban kezd elterjedni a paprika termelése is, melynek a kereskedelme Bátyán a század végén indul be igazán.

A bátyai társadalom szerkezetét a kertészkedés egyik terméke sem befolyásolta annyira, mint a paprika. Kialakult a termelök, a kikészítők és a kereskedők rétege a parasztság legéletrevalóbb részéből, akik magukat „pógárnak” nevezték. Hozzájuk kapcsolódtak a malomtulajdonosok, mint a helyi társadalom kiskapitalistái is. Az 1930-as évekre a paprika-termelők száma elérte a 400-at, vízi és szárazföldi malmok létesültek (többek közt 1891-ben a világ legnagyobbjaként a Merkler malom), kialakult a nagykereskedők rétege. (Fehér, 1996: 188. o.). A fellendülés a háborúig tartott.

A II. világháború és a kommunista éra rányomta a bélyegét a falura is. Az 1960-as népszámlálás adatai szerint Bátya még igazi parasztfalu. A 3320 lakosból a mezőgazdasági népesség száma 2440 (73,5\%), akik közül kereső 1388, miközben a település 1961-ben „szövetkezeti község” lett két TSZ-szel (amelyek később egyesültek). Ugyanakkor a '60-as és '70-es években a munkaképes lakosság nagy számban költözik el a faluból, főképpen Kalocsára. Mindezek ellenére 1974-ben az aktív keresők nagyobb része még a mezőgazdaságban, tehát főképpen a téeszben dolgozott (számuk 870 volt - az aktív keresők $60 \%$-a), bár jelentős a kalocsai üzemekbe ingázók száma is (Fehér, 2013). A mezőgazdaságból történő munkaerő kiáramlás folytatódott a rendszerváltásig, erősödve a gépesítés, a technológiai fejlesztések okozta következményekkel. Ugyanakkor a háztáji gazdálkodásban a paprika termesztése folyamatosan fennmaradt. 
A TSZ felbomlását követő privatizáció és kárpótlás az ország más részeihez hasonló sajátosságokkal zajlott itt is le, jelentősen átrendezve a birtok-, illetve tulajdon-viszonyokat. Mezőgazdasági termeléssel manapság már jóval kevesebben foglalkoznak, mint a rendszerváltás vagy a világháború előtt, de még mindig jellemzője a településnek. Miközben 1990 és 2011 között az országban, a Dél-Alföld régióban, Bács-Kiskunban és a Kalocsai térségben is gyakorlatilag harmadára esett az agrárium foglalkoztatásban betöltött súlya, Bátyán ez a csökkenés csak közel 50\%-os volt (1. táblázat). Az agrárium a nagyobb vállalkozásokban foglalkoztatottaknak, az őstermelőknek, a kisebb-nagyobb földeken és háztájiban gazdálkodó családoknak, családtagoknak jelent fö- vagy mellékállásban megélhetést.

1. táblázat: Mezőgazdasági foglalkoztatás Bátyán, 1990, 2001, 2011 (fö, \%)

\begin{tabular}{|c|c|c|c|c|c|}
\hline & \multicolumn{4}{|c|}{ Foglalkoztatottak } \\
\hline & & \multirow[t]{2}{*}{\begin{tabular}{|c|} 
összesen \\
\end{tabular}} & \multicolumn{3}{|c|}{ ebből a mezőgazdaságban és erdőgazdálkodásban* } \\
\hline & & & számuk & arányuk & számuk 1000 lakosra \\
\hline \multirow{5}{*}{ হু } & Bátya & 970 & 423 & $44 \%$ & 171,19 \\
\hline & Kalocsai kistérség & 25680 & 9207 & $36 \%$ & 152,28 \\
\hline & Bács-Kiskun megye & 239243 & 75588 & $32 \%$ & 134,31 \\
\hline & Dél-Alföldi régió & 602702 & 159902 & $27 \%$ & 111,98 \\
\hline & Magyarország & 4527157 & 699258 & $15 \%$ & 66,44 \\
\hline \multirow{5}{*}{$\stackrel{\overline{8}}{\stackrel{2}{2}}$} & Bátya & 635 & 121 & $19 \%$ & 53,23 \\
\hline & Kalocsai kistérség & 18825 & 2978 & $16 \%$ & 51,30 \\
\hline & Bács-Kiskun megye & 191550 & 26244 & $14 \%$ & 47,31 \\
\hline & Dél-Alföldi régió & 470875 & 58879 & $13 \%$ & 42,30 \\
\hline & Magyarország & 3690269 & 203106 & $6 \%$ & 19,81 \\
\hline \multirow{5}{*}{$\overline{\check{\nu}}$} & Bátya & 726 & 153 & $21 \%$ & 70,54 \\
\hline & Kalocsai kistérség & 18714 & 2009 & $11 \%$ & 37,29 \\
\hline & Bács-Kiskun megye & 198770 & 21191 & $11 \%$ & 39,35 \\
\hline & Dél-Alföldi régió & 493525 & 49451 & $10 \%$ & 37,02 \\
\hline & Magyarország & 3165018 & 173535 & $5 \%$ & 17,15 \\
\hline
\end{tabular}

*Megjegyzés: 1990 - Mezögazdaság, vadgazdálkodás, erdögazdálkodás és halászat; 2001 és 2011 - Mezögazdaság és erdögazdálkodás

Forrás: Népszámlálások adatai alapján saját szerkesztés, 2017

A kérdőíves felmérés alapján a megkérdezett bátyai háztartások kétötöde úgy nyilatkozott, hogy nem rendelkezik földterülettel (fontos leszögezni, hogy a válaszadók a konyhakertet jellemzően nem tekintik földtulajdonnak). Közel 50\% azok aránya, akik 1-5 ha közötti földtulajdonnal rendelkeznek. Az 5-10 ha-os tulajdon megoszlása 9\% körüli, míg a 10 ha feletti méretet a válaszadók kicsivel több, mint 5\%-a jelölte.

Megkértük a háztartásokat, hogy jelöljék meg azt a három legjellemzőbb terméket, terményt, melyet elöállítanak (2. ábra). Miközben a megkérdezettek közel 40\%-a jelezte, hogy nincs földtulajdona, gyakorlatilag a háztartások fele azt jelölte meg, hogy semmilyen mezőgazdasági terméket nem termel. Ez azt jelenti, hogy még a konyhakertjében sem termel zöldséget és gyümölcsöt. Bár ez a kép tovább árnyalható lenne, mindenesetre jól jelzi azt a tendenciát, amely a mai magyar falvakra jellemzö, és más kutatásunk is hasonlóan kimutatott. Azokban a háztartásokban, melyekben folytatnak - akár háztáji - termelést, a zöldségek, ettől elkülönítve a füszerpaprika, és a fokhagyma, továbbá a gabona termesztése emelhető ki. A korábban jellemző állattartás, illetve gyümölcstermesztés már csak nyomokban lelhető fel. A zöldségek között elsősorban a babot, hagymát, káposztát emelték ki (a külön kezelt paprika és a fokhagyma mellett), gabona esetén a búza és árpa, egyéb szántóföldi növény tekintetében (a 
külön kezelt kukorica mellett) a szója került elötérbe. Összességében elmondható, hogy a hagyományos paprikatermesztés a helyi termékösszetételben még tetten érhető.

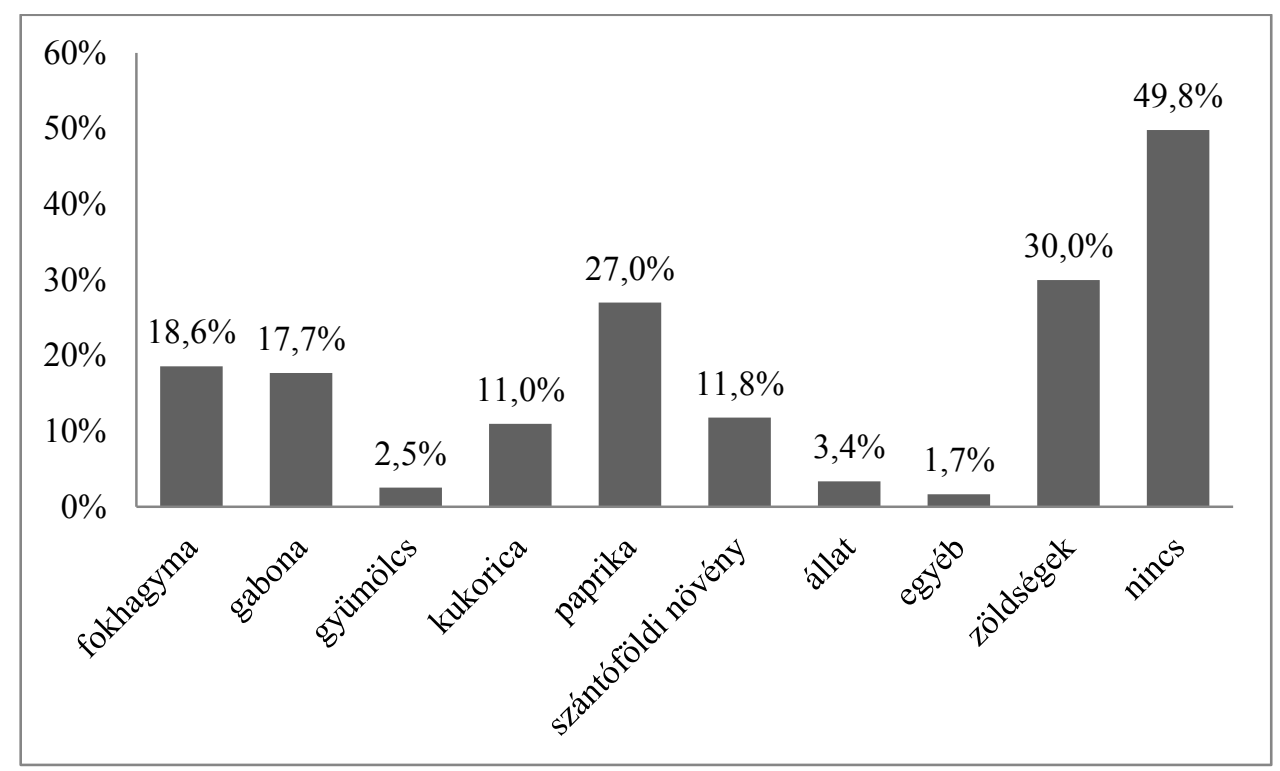

2. ábra: A válaszadók által termelt fő termények megoszlása (\%)

Megjegyzés: A három legjellemzöbbet kellett megadni

Forrás: Saját kutatás és szerkesztés, 2017

Azokat, akik mezőgazdasági termék-elöállítással foglalkoznak, megkérdeztük, hogy saját előállításra termelnek csak, vagy értékesítéssel is foglalkoznak. A válaszok alapján (3. ábra) a megkérdezett termelők háromnegyede értékesítésre termel, csupán egynegyedük az, aki teljes mértékben saját felhasználásra állít elő mezőgazdasági produktumot. Kiemelhető, hogy a megkérdezett termelők fele a teljes megtermelt mennyiséget értékesíti, tehát nem az önellátás, hanem az árutermelés a fó célja. Ugyanakkor a képet árnyalni kell, mivel ebben az értékesítésben elsősorban az alapanyag jelenik meg, a füszerpaprika-őrlemény, mint feldolgozott termék elsősorban mint addicionális, kiegészítő termék kap szerepet (tehát pl. a piacra az ismerősöknek kérésre visznek adott mennyiségű paprika örleményt).

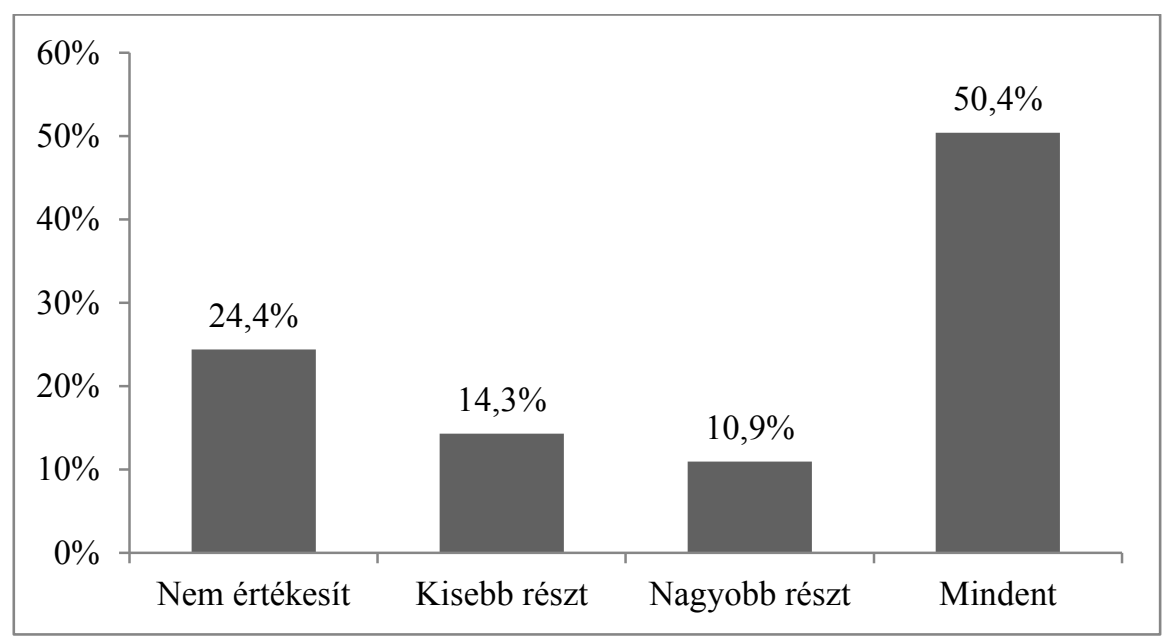

\section{3. ábra: A mezőgazdasági termékek értékesítésének megoszlása a termék-előállító válaszadók körében (\%)}

Forrás: Saját kutatás és szerkesztés, 2017

Rákérdeztünk arra, hogy aki értékesíti a termékét, az jellemzően hol teszi ezt meg. A válaszok alapján a legjellemzőbb megoldás a felvásárlóknak történő értékesítés. Ez egyaránt magában 
foglalja adott vállalatnak vagy feldolgozónak szerződéssel történő értékesítést, valamint az időszakos kereskedőknek, felvásárlóknak történő eladást (a paprika esetében a helyi Chili Trade nevü céget, Kalocsát, Hajóst és Kecelt emelték ki a megkérdezettek). Az árutermelök közel egyharmadának a budapesti nagybani piac a célterülete, és kiemelhető még a már meglévő bizalmi kapcsolatok alapján történő direkt, illetve a háznál, helyben történő indirekt értékesítés is. Ez utóbbiak kifejezetten jellemzőek az őrlemény értékesítés esetén.

A kérdőívezéssel kapott kvantitatív eredményeket a település vezetőivel, meghatározó személyiségeivel, valamint kifejezetten a mezőgazdasági termeléssel, paprika termesztéssel és feldolgozással foglalkozó szereplőkkel készült kvalitatív interjúk alaposan árnyalták. Alábbiakban kizárólag a paprikával kapcsolatos eredmények kerülnek bemutatásra.

Belletti és társai (2003) alapján a helyi termékek kapcsolódását egy adott térség vidékfejlesztéséhez az biztosítja, hogy ezen termékeket az előállítási helyszínükkel való szoros kötődés teszi igazán egyedivé, ami a keresletüket is nagymértékben befolyásolja. Így az érintett vidéki területeknek egyfajta potenciális erőforrásként kell tekinteniük ezekre a termékekre. Endrighi (1999) szerint a helyi, egyedi termékek alapvetően kétféle módon befolyásolhatják előállítási helyük környezetét: a) a termék sikere gazdasági hasznot hoz az azt elöállító vállalkozások számára, illetve a termék ismertségének növekedése magával húzza a helyi gazdaság egyéb szereplőit is (pl.: idegenforgalom, vendéglátás és kézművesség); b) a termék sikere többnyire csak a helyi lakosság bevonásával érhető el (pl.: munkaerőként alkalmazva), amely magával vonja a társadalmi kohézió és az identitástudat erősödését is. Fentiekből kiindulva vizsgáltuk a termék köré szerveződő szereplők helyzetét, a közöttük lévő kapcsolatot, a termékből származó hasznok megoszlását.

A paprika termelése kisebb területen, viszont intenzív gazdálkodással valósítható meg, ez jól illeszthető volt a bátyai gazdálkodás szerkezetébe, különösen a II. világháború előtt, de a szövetkezeti időkben is mind a közös müvelés, mind a háztáji gazdálkodás keretébe. A részes müvelésben gyakorlatilag a bátyai háztartások mindegyike részt vett. A paprika termöterülete a beszámolók alapján a 350 ha-t (volt, aki 500 ha-t mondott) is elérte a szövetkezet idején, ennek 90\%-át kézzel szedték. A szövetkezet feloszlása után létrejött utód társaságok, illetve nagyobb méretű (50-100 ha) gazdálkodók termelési szerkezetében kezdetben a szántóföldi zöldségtermesztés is hangsúlyos volt (benne a paprika, mellette pedig még a kapor, petrezselyem, csemege kukorica stb.), ám a fajszi öntözőfürtöt privatizálása után, a növekvő költségeknek és a külföldi importnak köszönhetően ezzel felhagytak. A nagyobb termelök egyértelmüen a szántóföldi növénytermesztésre (túlnyomóan gabona) rendezkedtek be.

Jelenleg hét-nyolc, mások szerint nagyjából tíz család foglalkozik „,nagyobb” volumenben a füszerpaprika termeléssel, ők azok, akik jellemzően korszerü szárítóval is rendelkeznek, és másnak is bérszárítanak, illetve nagyobb volumenben feldolgozzák az alapanyagot. A tapasztalataink és az interjúk alapján még annyi megjegyzés tehető, hogy jelentős számban találhatóak Bátyán olyan háztartások, melyek egészen kis volumenben, kis területen, sokszor háztáji gazdálkodásban, de termelnek paprikát. A jellemző felhasználás saját célú, illetve ebben az esetben is megemlíthető azoknak az értékesítési csatornáknak a szerepe, melyek az elmúlt évtizedekben alakultak ki. A szárítás vagy saját megoldású eszközökkel, vagy a nagyobb termelők komolyabb berendezéseinek bérlésével történik.

A paprika feldolgozással és kereskedelemmel kapcsolatban a Chili Trade Kft. emelhető ki. A cég, melynek kötődése van az egyik nagyobb helyi mezőgazdasági vállalkozáshoz, 1994-ben alakult, családi vállalkozásként indult. Jelenleg a legnagyobb foglalkoztató Bátyán, átlagosan 35 alkalmazottal. A cégnek a fokhagyma termék-előállítás is fontos profilja, de a legjelentősebb a füszerpaprika és a köré fonódó termékek elöállítása. Fontos leszögezni, hogy a cég nem állít elő hivatalosan Hungarikumnak számító, védjeggyel ellátott „kalocsai füszerpaprika- 
örleményt"2. Az alapanyagot a környékről szerzik be, szerződéses formában, de a közel 100 beszállító túlnyomó részt Bátyán kívüli (pl. Fajsz, Miske, Bogyiszló), ami a termék „helyi” múltját illetően ismét érdekes tény. A cég a termeléshez szükséges vetőmag alapanyagot döntően biztosítja. A helyi kistermelők részéröl sokszor felmerült az a vád, hogy a cég által feldolgozott alapanyag származása bizonytalan. Nyílván ebben szerepet játszik, hogy a Chili Trade Kft., mint a legnagyobb volumenü elöállító monopol helyzeténél fogva legyőzhetetlen versenytársat jelent a piac egy jelentős részének tekintetében. A vezetőséggel készült interjú alapján a termék útja az alapanyag előállítástól a feldolgozáson át a csomagolásig szigorúan nyomon van követve, szigorúan szabályozva van. A minőséget a hatóságok rendszeresen ellenőrzik. Az értékesítés túlnyomóan $(70 \%)$ országos szintü, elsősorban kisboltokban és idegenforgalmi szempontból kitüntetett helyeken történik. Kiskereskedelmi értékesítéssel ajándékbolt formájában Bátyán találkozhatunk. Multiknak nem szállítanak. Ami közös a kistermelöi értékesítéssel, hogy a cég esetén is fontos szerepet játszanak a 20-25 év alatt kialakult bizalmi kapcsolatok, melyek a - forgalom kb. 30\%-át kitevő - külföldre történő, döntően éttermeket. kisüzemeket célzó értékesítésnél is meghatározóak.

Pacciani és társai (2001) megállapítják, hogy a helyi, különleges termékek értéknövelésében érdekelt szereplők nagymértékben különbözhetnek egymástól, és mindegyik fél a saját érdekét tartja szem előtt. Egyes szereplők közvetlenül is részt vesznek a termék előállításában, míg mások csak közvetett szerepet töltenek be, esetenként nem is az előállítás helyszínén tevékenykednek. A szereplők érdekeltségeit alapvetően az határozhatja meg, hogy az érintettnek mi a célja, illetve hogy önmagának a régiónak, mint a termék elóállítási helyszínének milyen szerepet jut. Az érintettek célja alapján megkülönböztethetünk olyan stratégiát, amely csak magának a terméknek az előállítási és értékesítési folyamatára (az ellátási láncra) koncentrál, illetve olyat, amikor a helyi gazdaság és társadalom egésze a célcsoport (kiterjesztett nézőpont). Az előállítási helyszín a stratégiában betöltött szerepe alapján lehet egyszerüen csak egy minőségi ismertetőjel, de akár az adottságok kifejezője is. Minőségi ismertetőjelként (garanciaként) a származási hely pontos megjelölése arra szolgál, hogy segítsen a vásárló számára megkülönböztetni az adott terméket a többi, hasonló terméktől. Adottságok kifejezőjeként az előállítási hely egy gyüjtőfogalom, mely a régióhoz kötődő összes termék- és szolgáltatás-kosarának együttesét fejezi ki. A termék szoros értelemben vett ellátási lánca mellett figyelmet szán a kapcsolódó ágazatoknak is, és általánosságban véve szolgálja az adott térség érdekeit (idézi Török, 2013). A kalocsai füszerpaprika-őrleménnyel mint hungarikum termékkel, annak mint endogén eröforrásnak a szerepével kapcsolatban a termelésben és forgalmazásban érintett szereplőkkel készült interjúk alapján az alábbiak körvonalazhatóak:

A termék méltán érdemelte ki a címet. Ugyanakkor a megkérdezettek szerint a „kalocsai” megjelölés aggályos lehet, mivel a termék alapanyaga napjainkban gyakorlatilag Kalocsán kívüli települések termőterületén kerül hagyományosan előállításra. Mint sok más hungarikum élelmiszer esetén a helyi termelők megjegyezték, hogy a védjegy, a hivatalos eredetvédelem hiánya ellenére pontosan olyan (sőt, inkább jobb!) terméket állítanak elö, mint amelyet a vonatkozó szabályozás meghatároz ${ }^{3}$. Ennek ténye a biztosíték az állandó minőségre, a stabil vevőkörre, melynek fenntartása természetes érdeke az érintetteknek. A védjegy megszerzése azonban olyan plusz költségeket jelentene, mely még egy olyan nagyobb cégnek sem éri meg,

\footnotetext{
${ }^{2}$ Ennek - az interjúk során is megerösített - ténynek a fényében különösen érdekes, hogy a Hungarikumok Gyüjteményének honlapján, a kalocsai füszerpaprika őrlemény, mint hungarikum termék oldalon, a termék hivatalos weboldalaként a www.paprikavilag.hu cím van megadva, mely a Chili trade köré szerveződő Paprikavilág Kft., illetve ezen keresztül a Chili trade webáruházának az oldala.

${ }^{3}$ A helyi termékek minőségét, beltartalmát, szavatossági idejét, de még az árát is (kb. 1000Ft-al olcsóbb kg-onként) előbbre helyezték a termelők a hivatalosan, boltban kapható, eredetvédett termékekhez képest.
} 
mint a Chili Trade Kft.. Mindezek mellett alátámasztja a szakirodalmi megállapításokat az az egybehangzó vélemény, hogy a régi bizalmi kapcsolatra alapozó vevőkör a kalocsai termőterületről származó, de „,bátyai” paprikát keresi, tehát minőségi ismertetőjelként a vizsgált települést helyezi a hungarikum imázs mellé.

Problémaként merült fel, hogy hagyományos magyar fajták kiszorulnak, és helyüket külföldi hibrid fajták veszik át, amik viszont már nem tekinthetők hungarikum alapanyagnak. Azt is megemlítették, hogy több olyan háztartás, mely egyébként nem hivatalos formában értékesítést végez, nem maga termeli meg az őrleményt, vagy annak alapanyagát, illetve hogy olyan őstermelők is vannak, akik egyébként nem folytatnak gazdálkodást (vagy nem akkora volumenben, mint amilyenben értékesítenek).

Maga az a tény, hogy a füszerpaprika őrlemény hungarikummá lett nyilvánítva, nem jelentett igazán változást egyetlen érintett szereplőnek sem, egyrészt mivel hivatalosan nem állítanak elő hungarikumot, másrészt kapcsolataik, értékesítési csatornáik olyan régi bizalmi viszonyokon alapulnak, melyeket nem befolyásolt ez a tény. A minőség, ami ennek alapját képezi, töretlen.

Azok köre, akik valamilyen mennyiségben, de állítanak elő őrleményt, nehezen pontosítható a kutatás alapján. A Chili Trade-en kívül ,hivatalosan” senki nem foglalkozik vele, ám a becslések szerint még a háztartások legalább fele valamilyen mértékben érintett. Hét-nyolc nagyobb volumenủ (pár, esetenként 5-10 hektáron gazdálkodó) termelőt lehet azonosítani, Ök azok, akik - mint már korábban is szerepelt - nagyobb kapacitású szárítóval rendelkeznek, és bérszárítást is végeznek. Ezek a termelők vagy családon belül oldják meg az idénymunkákat, vagy esetenként 10-12 embernek jelentnek alkalmi foglalkoztatást. Embert találni általános véleményként egyre nehezebb ezekre a feladatokra. A problémakört Bátya esetében a közmunka program által történő munkaerö-elszívás is erősíti. Ehhez járul még, hogy a fiatalok elfordulása a mezőgazdálkodástól a paprika-termelésre is kihatással van. A füszerpaprika és őrlemény előállításának hagyományát már csak pár lelkes helyi fiatal gazdálkodó elhivatottsága viszi, viheti tovább. Erre kihatással van az is, hogy a termelési szerkezet a kevésbé kézimunka igényes termékek, az egyéb szántóföldi kultúrák, valamint a nagyobb gazdaságok esetén egyértelmüen a gabona irányába ment el.

Kitüzött cél volt annak felderítése is, hogy egy nemzeti szinten értelmezhető erőforrás köré kapcsolódó szolgáltatásokat, turisztikai termékeket is lehet-e füzni. A turisztikai termék olyan termékek, szolgáltatások, és élmények halmaza, amelynek célja a turista szükségleteinek és motivációnak komplex kielégítése. A turisztikai vonzerő, avagy attrakció pedig a turisztikai termék alapja (Lengyel, 1992; Michalkó, 2004). A turista utazási motivációját kielégítő vonzerővel rendelkező desztinációt választ, ugyanakkor a vonzerő meghatározza a komplex terméket alkotó többi szolgáltatás típusát (Nagy és Virág, 2014). Beszélhetünk elsődleges, fö vonzerőről, amiért a turisták adott térségbe érkeznek, és másodlagos, kiegészítő vonzerőről, amelyet a turista szintén vonzónak talál a fő vonzerőn túl (pl. helyi gasztronómia, szórakozás), és hozzájárul a terület komplex vonzerejének megítéléséhez (Puczkó és Rátz, 2011).

Tózsa és Zátori (2013) megállapítják, hogy fontos a hungarikumok turisztikai termékbe való integrálása, ugyanis olyan értékeket és egyben turisztikai erőforrásokat, vonzerőt vagy vonzerőelemet jelentenek, amelyekre alapozva egyedi, autentikus, újdonságértékkel rendelkező, megkülönböztethető desztinációs termékek alakíthatók ki. Ugyanakkor, a hungarikum mint turisztikai erőforrás önmagában nem sikertényező. Megfelelőképpen kommunikálni is kell a fogyasztók irányába. Az információ szolgáltatás kulcsfontosságú tényező az egyedi érték megtalálásában, valamint a hungarikumok turizmus általi népszerüsítésében egyaránt. A belföldi szegmens (és a határon túli magyarok) irányába a hungarikum mint brand és kiemelt érték kommunikációján van a hangsúly, a külföldi szegmens tekintetében inkább a 
hungarikumok bevonásával történő termékfejlesztés a fontosabb, amely megkülönbözteti a hazai ajánlatot a nemzetközi turisztikai piacon (Tózsa és Zátori, 2013).

A szakirodalmi megállapítások tükrében a füszerpaprika-örleményt mint egyfajta turisztikaivagy vonzerő értéket nem használja ki tudatos formában a település. Egyedül a Chili Trade Kft. építi be tervezetten a tevékenységébe, ami nyilván a cég profiljából vezethető le. A kínálat mintabolt, paprika múzeum, tájház, valamint gyárlátogatás (látogató folyosó) formájában érhető tetten, amit kiegészít a kalocsai turisztikai látogató központ tevékenysége. Ennek során a nyolc alkalmazottat foglalkoztató központ a Kalocsára látogató turistákat gumikerekes kisvonattal szállítja ki Bátyára a mintaboltba, aztán vissza. A mintaboltban a paprika mellett különböző kisebb emléktárgyakat lehet vásárolni. Ez az attrakció semmilyen együttműködést nem valósít meg a helyi lakosok, termelök vagy más települési szereplök tekintetében.

A helyi „turisztikai kínálat” ezen kívül az út mellett, a porták előtt felállított állványokra kilógatott paprika (és fokhagyma) füzérekben, őrleményes zsákocskákban merül ki.

A helyi szereplők (önkormányzat, termelők, értékesítők, turisztikai vállalkozások, vendéglátás stb.) közt tehát nem azonosítható konkrét, szervezett formában tetten érhető együttmüködés (kivéve a Chili Trade Kft. szerződéses beszállítói hálózatát, vagy kisebb termelöi bérleményeket), nincs sem a termelésben, sem a feldolgozásban, értékesítésben, marketingben, turizmusban stb. kooperáció. A környék legnagyobb szereplöjével, az eredetvédett terméket előállító Kalocsai Füszerpaprika Rt.-vel sem nevesíthető ilyen kapcsolat (az Rt. által előállított termékek minőségét egyébként a helyi kistermelők általánosan megkérdőjelezték, és a saját, helyi termékeik minősége mögé helyezték). A településen nincs tematikus, a paprikára építő koncepció, a hagyományos gasztronómiai fesztivál is a fokhagyma köré van felépítve.

Magának a terméknek az ismertségét egyébként országosan is a felső szegmensbe helyezték a megkérdezettek, a hungarikumok közt is dobogós helyen szerepeltetve, hiszen azt ,,mindenki ismeri". A külföldiek számára az ismertség relatív, aki célzottan pirospaprikát keres, az ismeri a nevet, és az bukkan fel a településen vásárlási céllal, aki csak a magyar paprika imázsról hallott, az nem tud különbséget tenni pirospaprika és pirospaprika közt.

Végezetül egy érdekes adalék arra vonatkozólag, hogy a paprika mint helyi, egyedi termék, endogén erőforrás hogyan tagozódik be a település jelenlegi életébe, és a helyi identitástudatba.

A kérdőívben megkértük a válaszadókat, hogy mondják el, mire a legbüszkébbek Bátya tekintetében. A válaszok alapján (4. ábra) a településre jellemző termékek (tehát nem csak a paprika) tekintetében is csak a megkérdezettek $16 \%$-a tett említést, a paprikához köthetően csupán 9\%, míg kifejezetten a termékre (őrleményre) vonatkozóan mindössze a válaszadók 5\%a. Ez a paprika szerepét és múltját alapul véve, nagyon csekély aránynak mondható.

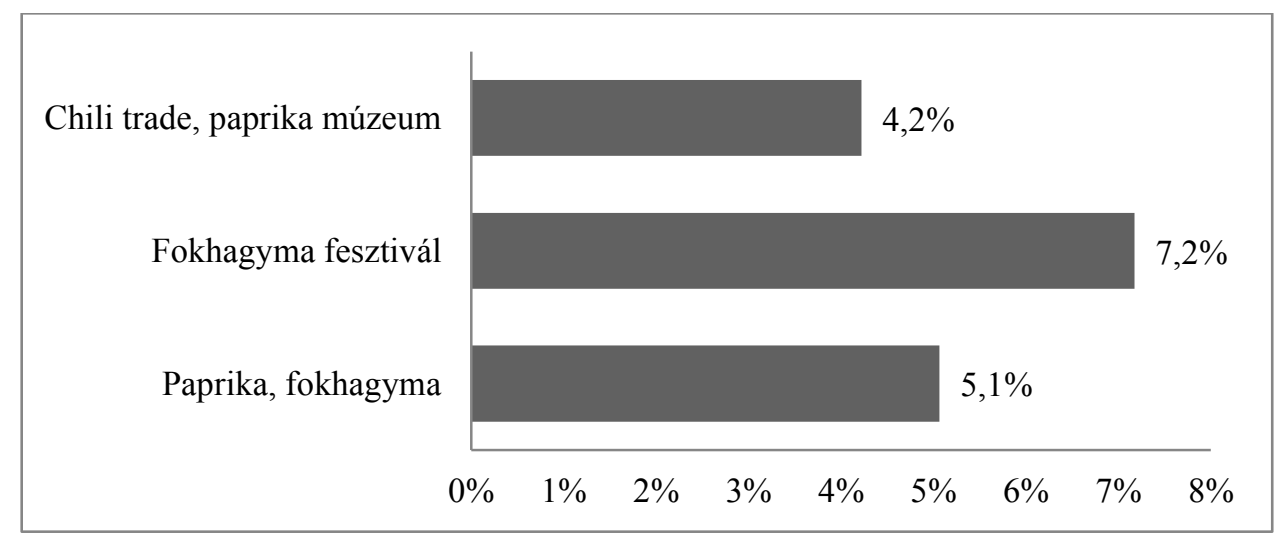

4. ábra: Mire a legbüszkébbek Bátyán - a válaszok megoszlása (\%)

Forrás: saját kutatás és szerkesztés, 2017 


\section{Következtetések}

Korábbi, általánosan a helyi mezőgazdaság szerepét taglaló cikkünkben már problémaként azonosítottuk az erősen visszaeső agrárfoglalkoztatást, illetve az agrárfoglalkoztatottak korstruktúrájának vizsgálatából következő gondot - azt a tényt, hogy a fiatal generáció már nem érdeklődik a primer ágazatban rejlő lehetőségek iránt. A bátyai termelés tekintetében szükül a diverzifikáció, a korábbi fajsúlyos szerepéhez mérten lassan már csak a háztájikra korlátozódik a zöldség, és benne kiemeltként a füszerpaprika termelése. Ezek eltünésével nem csak a helyi foglalkoztatási lehetőségek, hanem a helyi gazdaság lehetőségei is korlátozódnak. Az egyes szereplök elszigetelten, egymástól függetlenül, az egyéni profitokat igyekeznek maximalizálni, településszintü és érdekű kooperációra, koordinációra, fejlesztésekre nincs törekvés.

Gondot okoz, hogy a helyi termelési és birtokszerkezet átalakulása, a romló korszerkezet, a tőkehiány és az erodálódó „helyi tudás” megnehezíti a tradíciók folytatását. Néhány lelkes helyi fiatal, aki még elhivatottságot, és üzleti lehetőséget érez a hagyományok továbbvitelében, valamint a még meglévő idősebb generáció fenntarthatja ezt a tradíciót, de megfelelő támogatáspolitika, a kézi munkát elvégezni tudó és akaró munkaerő, illetve tudatos, összehangolt helyi politika és együttmüködés nélkül ennek a távlata bizonytalan. Nagyon megnehezíti a dolgokat, hogy az igen jelentős, legtöbbször munkacsúcsokban jelentkező kézimunka igényt sem lehet kielégíteni (erre esetenként még a környék egyéb településeiröl, Kalocsáról is igen nehéz embert szerezni). Ebben szerepet játszik az érintettek beszámolója alapján a helyi közmunkaprogram is, mely a kényelmesebb és biztosabb formájával „eltereli” a munkaerőt a fárasztó agrármunkától. A közmunkaprogram évről évre több embert köt le, bár a térségi vagy országos átlaghoz viszonyítva fajlagosan (lakosságszámra vetítve) még mindig kisebb mértékben (2. táblázat).

2. Táblázat: Közfoglalkoztatásban részt vevők havi átlagos száma, 2013-2016 (fö)

\begin{tabular}{|l|c|c|c|c|c|c|c|c|}
\hline & \multicolumn{2}{|c|}{$\mathbf{2 0 1 3}$} & \multicolumn{2}{c|}{$\mathbf{2 0 1 4}$} & \multicolumn{2}{c|}{$\mathbf{2 0 1 5}$} & \multicolumn{2}{c|}{$\mathbf{2 0 1 6}$} \\
\cline { 2 - 10 } & fö & $\begin{array}{c}\text { fö/ezer } \\
\text { lakos }\end{array}$ & fö & $\begin{array}{c}\text { fö/ezer } \\
\text { lakos }\end{array}$ & fö & $\begin{array}{c}\text { fö/ezer } \\
\text { lakos }\end{array}$ & fó & $\begin{array}{c}\text { fö/ezer } \\
\text { lakos }\end{array}$ \\
\hline Bátya & 30 & 14,1 & 34 & 16,1 & 39 & 18,6 & 60 & 28,6 \\
\hline Kalocsai kistérség & 1191 & 22,7 & 1411 & 27,2 & 1464 & 28,5 & 3194 & 62,2 \\
\hline Kalocsai járás & 1200 & 22,8 & 1421 & 27,3 & 1473 & 28,6 & 3213 & 62,3 \\
\hline Bács-Kiskun & 5780 & 10,8 & 8058 & 15,2 & 8719 & 16,5 & 20455 & 38,7 \\
\hline Dél-Alföld & 19550 & 14,8 & 27378 & 20,9 & 30569 & 23,4 & 65932 & 50,5 \\
\hline Magyarország & 126841 & 12,6 & 178544 & 17,8 & 207259 & 20,7 & 446861 & 44,6 \\
\hline
\end{tabular}

Forrás: BM adatok alapján saját szerkesztés, 2017

Az endogén fejlesztésre, a hungarikumokra vonatkozó szakirodalom fényében körvonalazódik, hogy a település összességében messze nem aknázza ki ezen erőforrásban rejlő lehetőségeket, sőt, a korábbi lehetőségek beszükülésének lehetünk inkább tanúi. A területi versennyel foglalkozó megállapítások alapján inkább az valószínüsíthető jelen helyzet alapján, hogy a település versenyelőnyeként azonosítható hungarikum (jellegü) termék termelése várhatóan minimálisra, néhány termelő számára hasznot hajtó lehetőséggé korlátozódik. A mezőgazdaság általános visszaszorulása vagy elöregedése mellett, a település, a térség különlegességét jelentő kézimunka-igényes füszerpaprika termelésének visszaesése felveti annak a lehetőségét, hogy a település elveszti azt a helyi sajátosságot, mely korábban jellemzője volt, és ami kiemelte a hazai települések sorából.

Ezek ellenére a füszerpaprika termelés, mely hivatalos (védjeggyel bizonyított) formában nem, azonban a régi kapcsolatokon, bizalmi viszonyokon alapulva informálisan jelen van a településen, még egyelőre sajátos versenyelönye a falunak. A helyi gazdaságfejlesztés számára 
fentiek így még alapként jöhetnek szóba. Ezeknek az adottságoknak a kihasználása feltétlenül tudatosabban és célirányosabban javasolt. Megoldásként körvonalazódik az önkormányzati gazdálkodás (benne elsősorban a füszerpaprika termesztés) beindítása, a turisztikai célú gazdaságdiverzifikálás, a termékláncok menti kooperáció megteremtése, valamint a fiatal termelők célirányosabb segítése (természetesen ez utóbbi nem csak helyi szintű feladat).

\section{Felhasznált irodalom}

1. Áldorfai Gy. - Czabadai L.(2014): Helyi válaszok a globális kihívásokra. Acta Carolus Robertus 4 (2), pp. 9-18.

2. Áldorfai Gy. - Topa Z. - Káposzta J. (2015): The planning of the Hungarian local development strategies by using CLLD approach. Acta Avada (2), pp. 13-22

3. Bakos I. M. - Topa Z. (2016): The Contribution of Local Food to Tourism in Hungary. Contemporary Research On Organization Management And Administration 4 (2), pp. 63-74.

4. Belletti et al. (2003). Paths of rural development based on typical products: a comparison between alternative strategies. In: Cristovao A. - Omodei Z. L. (Eds.): Farming and rural systems research and extension - Local identities and globalisation. Fifth IFSA European Symposium Florence. Firenze: ARSIA, pp.384-395.

5. Cernea M. (1992) The Building Blocks of Participation. Washington: World Bank

6. Chesire, P. C. (2003): Territorial competition: lessons for (innovation) policy. In: Bröcker J. - Dohse, D. - Soltwedel, R (Eds.): Innovation clusters and interregional competition. Heidelberg: Springer, pp. 331-346.

7. EC (1999): Sixth Periodic Report on the Social and Economic Situation and Development of Regions in the European Union. European Commission: Luxembourg

8. EC (2005): 1698/2005/EK - A Tanács rendelete (2005. szeptember 20.) az Európai Mezőgazdasági Vidékfejlesztési Alapból nyújtandó vidékfejlesztési támogatásról. OJ L 277 (2005. 10. 21). Európai Közösségek, Luxemburg

9. Endrighi E. (1999): La valorizzazione delle produzioni tipiche locali. Dal concetto di valore alle indicazioni operative. (The valorisation of typical local products. From the concept of value to the operative indications). Rivista di Economia Agraria LIV (1), pp. 3-26.

10. Fehér Z. (2013): „Sürgősen eladó háromszáz négyszögöl termőföld...”. Egy sárközi kertészkedő falu népének és földjének helyzete a téeszvilág után. Hitel 26 (2), pp. 195 221.

11. Horváth Gy. (Szerk.) (2006): Régiók és települések versenyképessége. Pécs: MTA RKK

12. Káposzta J. (2007): Regionális gazdaságtan. Gödöllő: SZIE GTK

13. Kassai, Zs. - Káposzta, J. - Ritter, K. - Dávid, L. - Nagy, H. - Farkas, T. (2016): The territorial significance of food hungaricums: the case of pálinka. Romanian Journal of Regional Science 10 (2), pp. 64-84.

14. Kopasz M. (2005): Multifuncionális mezőgazdaság az EU törekvéseinek összhangjában. A Falu (1), pp. 51-60.

15. Kulcsár L. (szerk.) (2006): Vidékfejlesztés. Gödöllő: SZIE

16. Lengyel I. (2003): Verseny és területi fejlődés: térségek versenyképessége Magyarországon. Szeged: JATEPress

17. Lengyel M. (1992): A turizmus általános elmélete. Budapest: Viva Kft

18. Lowe P. - Murdoch J. - Ward N. (1995): Networks in Rural Development: beyond exogenous and endogenous models. In: Ploeg J. D. van der - Dijk G. van (Ed.): Beyond modernisation: The impact of endogenous rural development Assen: Van Gorcum. 87105. p. 
19. Lukovics M. - Kovács P. (2008): Eljárás a területi versenyképesség mérésére. Területi Statisztika (3) 245-263. p.

20. Madarász I. (2004): A vidék funkciói az Európai Unióban. A Falu (4), pp. 35-43.

21. Michalkó G. (2004): A turizmuselmélet alapjai. Székesfehérvár: Kodolányi János Föiskola

22. Moseley, M. J. (2003): Rural Development Principles and Practice. London: Sage

23. Murdoch J. (1995): Sustainable Rural Development: Towards a research agenda. Regional Studies (5), pp. 479-499.

24. Nagy A. - Virág Á. (2014): Destination management in Hungary. Vestnik Apk Stavropolya / Agricultural Bulletin Of Stavropol Region 1 (1), pp. 41-44.

25. Nagy H. - Tóth T. - Oláh I. (2012): The role of local markets in the sustainable economic development of Hungarian rural areas. Visegrad Journal On Bioeconomy And Sustainable Development 1 (1), pp. 27-31.

26. Pacciani A. et al. (2001): The role of typical products in fostering rural development and the effects of regulation (EEC) 2081/92. http://www.origin-food.org/pdf/partners/belmarscaparole.pdf

27. Ploeg, J. D. van der - Dijk, G. van (szerk.) (1995): Beyond Modernization: The Impact of Endogenous Rural Development. Assen, The Netherlands: Van Gorcum

28. Puczkó L. - Rátz T. (2011): Az attrakciótól az élményig - A látogatómenedzsment módszerei. Budapest: Akadémia Kiadó

29. Ritter, K. - Virág, Á. (2015): Hungaricums - the role of endogenous resources in rural development through the example of Tokaj wine region. In: Jedynak, W. - Kinal, J. (Ed.): Selected aspects of socio-economical changes in a post-modern society. Rzeszów: University of Rzeszów. 7-16. p.

30. Tóth T. - Káposzta J. (szerk.)(2014): Tervezési módszerek és eljárások a vidékfejlesztésben (elmélet) Gödöllő: Szent István Egyetemi Kiadó

31. Tózsa I. - Zátori A. (2013): Hungarikumok. [Corvinus Turizmus Kompetencia Központ Szakkönyvsorozat - 1.] Budapest: Budapesti Corvinus Egyetem GK KTI Turizmus Kompetencia Központ

32. Török Á. (2013): Hungarikumok - Magyarország földrajzi árujelzői? Az eredetvédelem szerepe a XXI. századi mezőgazdaságban és élelmiszertermelésben - a pálinka példájának tanulságai. PhD értekezés. Budapest: Corvinus Egyetem 